Covered in: CrossRef; RePEC; CEEOL; Google Scholar.

2019, Volume 1, Issue 1, pages: 22-32 | doi: 10.18662/jmsw/02

\section{Controversies Regarding the Status of the Natural Person in International Public Law}

\section{Alexandra HUIDU1}

${ }^{1} \mathrm{PhD}$ Student, Doctoral School of Sociology, University of Oradea, Romania \& Lumen Research Center in Social and Humanistic Sciences, Iaşi, Romania, andrahuidu@yahoo.com
Abstract: International public law is, by its very nature, an area of controversy. Some are more easily resolved, others seem, at least for the moment, to be unresolved to such a manner that all divergent opinions could be reconciled. And the issue to be addressed has stirred up strong controversies and complex arguments, both on one side of the barricade and on the other. The question remains without an unanimous answer, and the literature presents us with several opinions. Is the natural person a subject of public international law or not? The controversial subjects of public international law are the natural persons, the legal persons and the non-governmental organizations. The literature calls them limited and subsidiary subjects of international public law. The old international public law recognizes only the state as its subject. In the evolution of international relations, however, a series of regulations regarding the natural persons appeared, which made it possible for them to become subjects of international law. The debate over this issue developed especially in the 1920s, after the creation of the Permanent Court of International Justice and later, after the Second World War, and at present new arguments have been added.

Keywords: international public law; natural person; procedural rights.

How to cite: Huidu, A. (2019). Controversies Regarding the Status of the Natural Person in International Public Law. Journal of Mediation \& Social Welfare, 1(1), 22-32. doi:10.18662/jmsw/02 


\section{Introducere}

Reglementările internaționale referitoare la persoana fizică cunosc două faze distincte. Într-o primă fază, întâlnim reglementări pentru reprimarea unor fapte săvârşite de persoanele fizice ca infracțiuni internaționale. Convențiile internaționale încheiate în acest sens prevăd instituirea de instanțe internaționale. $\mathrm{O}$ a doua fază, mai recentă, creează un sistem de protecție avansat a persoanei fizice, realizat pe mai multe planuri: protecția apatrizilor şi refugiaților, a gupurilor etnice, religioase, lingvistice, a drepturilor omului. Aceste reglementări constituie un element determinant pentru dezvoltarea actuală a dreptului internaţional public ca un drept al oamenilor şi nu numai al statelor.

Există, astfel, trei concepții diferite. Într-o primă concepție, datând din perioada interbelică, se consideră (Scelle, cit. de Miga-Beşteliu, 2003) că doar persoanele fizice sunt subiecte de drept internațional public. Această concepție rămâne minoritară. Poate fi amintit printre susţinătorii săi G. Scelle (cit. de Miga-Beşteliu, 2003: 160) care, plecând de la ideea că statul este doar o ficțiune a dreptului, un element organizatoric cu valoare instrumentală al cărui rol este să promoveze interesul colectiv, iar actele sale sunt puse în aplicare prin intermediul cetățenilor care îl formează, concluzionează că aceştia ar fi singurii subiecți de drept internațional.

Într-o a doua opinie, se susţine (Janis, 1984) că indivizii sunt subiecți de drept internațional public alături de alte entitaăţi, ca statele şi organizațiile internaționale.

Însă cea mai larg acceptată teză (Andronovici, 1993; Niciu, 1995) este cea care consideră persoanele fizice doar subiecte de drept intern, nu şi de drept internațional. "Persoana fizică nu e subiect direct al drepturilor stabilite de dreptul internaţional public cu privire la ea, ci obiect direct al acestor drepturi" (Niciu, 1995: 134).

Gh. Moca (1983: 263-264) consideră că prin însăşi caracterul său consensual, recunoscut ca atare la nivel interstatal, dreptul internațional exclude orice legătură între normele sale şi calitatea persoanelor fizice de a fi subiecți ai acestei ramuri de drept. Poziţia individului pe plan internaţional este, totuşi, la dispoziția fiecărui stat. Orice convenție internaţională ce conţine dispoziții referitoare la persoana fizică este rezultatul acordului de voinţă dintre statele în cauză, prevederile aplicabile indivizilor luând naştere din raporturile juridice dintre statele respective (Popa, Petrişor, \& Cozmâncă, 1994). 


\section{Raporturile juridice internaţionale şi statutul persoanei fizice raportat la acestea}

Normele de drept internaţional sunt creaţia exclusivă a statelor, statele fiind singurii subiecți cărora li se adresează aceste norme, ele fiind singurele care au capacitatea, atributele şi mijloacele de a le aplica. Drepturile şi obigațiile internaționale revin statelor. Persoanele fizice, cetățeni ai statelor, supuşi suveranității şi jurisdicției acestora, pot beneficia de drepturile şi îndeplini obligațiile asumate de statele lor, iar asta nu direct, ci prin intermediul legislației interne care ratifică instrumentele internaţionale.

"În raporturile juridice internaționale, persoana fizică nu apare - atât din punct de vedere procedural, cât şi substanțial - decât ca beneficiarul mediat al unor norme şi nu ca subiect activ, creator şi destinatar al normelor de drept internațional public" (Barbu, 2008). Ea nu deține o capacitate juridică internațională, care să îi fie proprie şi care să fie, în acelaşi timp, autonomă (sau independentă) în raport cu statele. Dacă statul, la un moment anume, ar decide sa părăsească sistemul unei anumite convenții internaționale la care a aderat anterior, ori dacă nu ar avea semnată o astfel de convenție, persoana fizică, fară "acoperirea" unei participări directe a statului, nu ar avea nicio calitate juridică în faţa organelor şi instanţelor internaționale (Barbu, 2008). C. Andronovici afirma că "individul poate fi considerat cel mult destinatar indirect al normelor dreptului internaţional contemporan" (Andronovici, 1993: 117).

Chiar dacă există situaţii în care persoanei fizice i se recunoaşte statutul de titulară a unor drepturi şi obligații atunci când intră în raporturi juridice nemijlocite cu o serie de subiecți de drept internațional, aceasta nu este o condiție unică pentru a califica automat persoana fizică ca fiind subiect de drept internațional public (Barbu, 2008). O altă condiție ar trebui îndeplinită pentru a conferi această calitate persoanei fizice, mai exact aceasta ar trebui să participe inclusiv la crearea normelor acestei ramuri de drept. Simone Dreyfuss susține că "pentru aceasta ar fi necesară o transformare a societăţii internaţionale, în sensul estompării rolului statului” (Dreyfuss, 1968: 68).

Doar din aceste căteva opinii, prezentate succinct, se poate observa cât de complexă este problema pusă în discuție. Aşadar, argumentele, atât pro, cât şi contra, stârnesc un real interes.

Se susține (Barbu, 2008) că, întrucât în dreptul internațional sunt consecrate prevederi privind drepturile şi libertățile fundamentale ale omului, persoana fizică ar fi devenit subiect al dreptului internațional. În general, in dreptul internaţional se poate vorbi de o umanizare a acestuia, în sensul că 
normele şi instituțiile care urmăresc asigurarea unei protecţii drepturilor şi libertăţilor individuale sunt din ce în ce mai numeroase. Individul este nu doar beneficiarul final al acestor prevederi şi instituții, dar se remarcă inclusiv faptul că îi revin şi prerogative sporite (Barbu, 2008).

Art. 20 alin. 2 din Constituția României nu este singular între constituțiile sau legile organice ale statelor care stabilesc că tratatele internaționale ce conțin prevederi în legătură cu drepturile omului se aplică in mod direct în ordinea juridică internă a statelor parte la tratate sau că dispozițiile lor inlatură aplicarea unor legi interne contrare.

Acte care consacră protecția internaţională a drepturilor omului sunt: Declarația Universală a Drepturilor Omului (UN, 1948), cele două pacte din anul 1966 - Pactul privind drepturile economice, sociale şi culturale (UN, 1966a) şi Pactul drepturilor civile şi politice ale omului (UN,1966b), Convenția privind lichidarea discriminării rasiale (UN, 1965).

Aşadar, în susținerea calității de subiect de drept internațional a persoanei fizice se poate argument că, semnând şi ratificând convențiile acestea şi carta O.N.U., comunitatea internațională a recunoscut că drepturile şi libertăţile omului nu mai sunt o problemă în limitele jurisdicţiei naţionale şi, prin urmare, prin Cartă au fost conferite în mod direct individului prerogative specifice dreptului internațional.

Dar acest lucru nu înlatură posibilitatea ca fiecare stat să îşi exercite în mod discreționar, în conformitate cu suveranitatea sa, atributele în acest domeniu. Reglementările de drept internaţional public iau naştere ca urmare a acordului dintre state suverane, se adresează direct statelor şi dau naştere, în ceea ce le priveşte, la drepturi şi obligații de a pune în aplicare aceste reglementări şi de a le asigura aplicabilitatea prin intermediul unor mijloace care sunt stabilite la nivelul jurisdicției naționale, pentru populația de pe teritoriul lor, colaborând totodată pe plan internațional în acest sens. Indivizii beneficiază de aceste drepturi în măsura în care acestea sunt prevăzute în legislația internă a statelor de care aparțin. Doar statele au mijloacele efective, juridice şi materiale, de a asigura protecția reală a acestor drepturi. In legătură cu normele juridice privind ocrotirea internaţională a minorităților naționale, tot statelor interesate le aparţine dreptul la petiție, şi nu persoanelor luate individual. In acelaşi timp, printr-o hotărâre a Curţii Permanente de Justiție Internațională $\mathrm{s}-\mathrm{a}$ stabilit că o convenție internaţională nu poate crea drepturi şi obligații pentru particulari (PCIJ, 1928a). 


\section{Norme internaţionale care susțin calitatea de subiect de drept internațional a persoanei fizice}

Un element care susține calitatea de subiect de drept internațional a persoanelor fizice este reprezentat şi de reglementările privitoare la protecția diplomatică şi consulară a cetățenilor unui stat când se află în străinatăte. Dar când interesele unei persoane au fost prejudiciate de un stat străin, persoana respectivă îşi va putea asigura apărarea intereselor sale prin intermediul statului al cărui cetățean este, prin raporturile interstatale dintre statul al cărui cetățean este şi cel în care i s-au prejudiciat interesele, chiar dacă va face asta in temeiul instituției de drept internațional a protecției diplomatice (Niciu, 1995: 133). "Protecția diplomatică şi dreptul de azil sunt drepturi ale statelor, care le pot acorda sau nu persoanelor fizice, iar nu un drept direct al acestora" (Niciu, 1995). Relevante în acest sens sunt hotărârile Curții Permanente de Justiție Internaționale în cauzele concesiunilor Mavrommatis (CPIJ, 1925), uzina Chorzw (CPIJ, 1928a), căile ferate Panevezys Suldntiskis (CPIJ, 1939).

Asemenea raporturi juridice sunt raporturi de la stat la stat, care se stabilesc atunci când, în temeiul protecției juridice pe care un stat îl are asupra cetățenilor săi aflați pe teritoriul unui alt stat, cere acestuia să repare prejudiciul suferit de către cetățenii săi (Geamănu, 1995: 338).

Dreptul internațional cuprinde norme care asigură protecție juridică persoanelor fizice cu statut de funcționari publici, acesta constituind un alt argument care ar putea susține calitatea persoanei fizice de subiect al dreptului internațional. Dar dreptul internaţional se adresează acestora din punct de vedere funcțional, ca agenți ai organizațiilor internaționale create prin acordul statelor, şi nu ca persone fizice. Protecția drepturilor subiective civile (Ignătescu, 2013) se realizează în baza unui temei indirect, nu direct.

Un alt argument care susţine teza conform căreia persoanele fizice sunt subiecte de drept internațional, pe acelasi plan cu statele, este cel care are în vedere faptul că acestea sunt subiecte ale răspunderii penale internaționale. Un astfel de exemplu este judecarea criminalilor de război de după al Doilea Război Mondial de către tribunalele internaționale de la Nurmberg şi Tokyo. Dar în acest caz, tribunalele nu au judecat decât pe principalii criminali de război, ceilalți fiind judecați de tribunalele interne. "Deci, calitatea de autori ai crimelor internaționale nu le conferă acestor persoane calitatea de subiect de drept internațional" (Diaconu,1995: 80). Răspunderea penală a acestor persoane fizice este o consecință a răspunderii statelor, care au săvârşit acte ilicite, şi se datorează importanței poziției acestor persoane la acel moment în cadrul apartului de stat, ca atare 
persoanele fizice răspund în calitate de reprezentante ale organelor de stat, numai că judecata se face de către instanțele internaționale. În general, dispozițiile privind infracțiunile internaționale nu pot fi aplicate direct persoanelor fizice decât prin excepții acceptate de state prin convenții incheiate între ele. Căci, în general, autorii nu sunt pedepsiți pe baza prevederilor convențiilor internaţionale, ci a reglementărilor adoptate în dreptul intern ca urmare a ratificării de catre state a convențiilor respective. $\mathrm{Nu}$ există nicio instanță internațională a carei competență personală să se extindă asupra indivizilor cetățeni ai diferitelor state.

Argumentul cel mai important al tezei conform căreia persoana fizică este subiect de drept internațional, cel legat de apelul individual la curțile internaţionale, este şi cel mai controversat. Problema care se pune este ca peroana fizică, în anumite situații particulare, să aibă dreptul de a sta în judecată în fața instanțelor internaționale în baza unei calități proprii, având dreptul sî declanşeze o acțiune în fața acestor instanțe, de unde rezută că persoana fizică devine prin aceasta subiect de drept internațional.

Se pot aduce în sprijinul acestei teze următoarele argumente: dispozițiile Convenției Europene pentru Protecția Drepturilor Omului referitoare la Comisia şi Curtea Europeană a Drepturilor Omului, regulile de procedură ale Curților de Justiţie ale Comunităților Europene, Protocolul facultativ al Pactului internațional privitor la drepturile civile şi politice adoptat in cadrul O.N.U. Proceduri asemănătoare au loc în cadrul unor comisii şi comitete rezultate în urma adoptării unor convenții speciale în unele domenii, cum ar fi: Subcomisia pentru prevenirea discriminării şi protecția minoritatilor, Comisia privind statutul femeii, Comitetul privind eliminarea discriminărilor rasiale, Comitetul împotriva torturii etc. Ca o concluzie la aceste argumente, Paul Reuter (1993) susținea că persoana fizică este subiect de drept internaţional numai din momentul în care are acces la procedurile în faţa organizațiilor internaţionale.

Dar adversarii acestei teze (Barbu, 2008) susțin că, în general, dreptul internaţional nu prevede posibilitatea persoanelor fizice de a avea drept de acțiune directă în procedurile judiciare internaționale în vederea obligării pe această cale a statului la respectarea sau asigurarea drepturilor care îi sunt recunoscute, concluzionând că individul nu poate acționa în afara cadrului statal. Argumentele de mai sus se bazează pe o serie de dispoziții din convențiile internaționale, cele mai des invocate fiind cele cuprinse de Convenția Europeană a Drepturilor Omului. 


\section{Studiu de caz: recursul individual conform dispozițiilor Convenției Europene a Drepturilor Omului}

În baza Protocolului nr. 9 din septembrie 1990, care modifică prevederile Convenției Europene a Drepturilor Omului, persoana fizică poate să intenteze acțiuni în fața Curții Europene a Drepturilor Omului. Articolul 25 din Convenție autorizează Comisia să primească cereri din pertea "oricărei persone fizice, oricărei organizații neguvernamentale şi a oricăror grupuri de particulari, care se pretind victimă a unei încălcări din partea unei Inalte Părți contractante în tot ceea ce priveşte drepturile recunoscute în prezenta Convenție" (art. 25 CEDO). Conform paragrafului $1 \mathrm{al}$ art. 25, "atunci când un stat recunoaşte dreptul la recurs individual, el se angajează să nu împiedice prin nicio măsura exercitarea eficace a acestui drept" (art. 25 para. 1 CEDO).

Art. 26 stabileşte condițiile de admisibilitate a recursurilor individuale: Comisia nu poate fi sesizată decât după epuizarea căilor de recurs interne, astfel cum rezultă din principiile de drept internaţional general recunoscute, şi în termen de şase luni, începând de la data deciziei interne definitive.

Reclamantul trebuie să îndeplinească, înainte de sesizarea instanței internaționale, condiția de a epuiza toate mijloacele procedurale puse la dispoziție de legea națională (căile de recurs interne), ceea ce reflectă principiul general de drept internaţional întemeiat pe convingerea că un stat trebuie să poată îndrepta o eventuală încălcare a obligațiilor sale internaţionale pe căi juridice interne proprii, înainte de a fi supus unui control şi/sau unei supravegheri la nivel internațional (ECHR, 1980). Comisia şi/sau Curtea se vor ocupa de caz atunci când autoritățile statale nu îndeplinesc dreptul încălcat şi nu acordă o reparație echitabilă ca efect al acelei încălcări.

In interpretarea pe care a dat-o expresiei de "epuizare a recursurilor interne", Curtea Europeană a Drepturilor Omului a apreciat în mai multe rânduri că un reclamant trebuie sa epuizeze toate recursurile oferite de dreptul intern, cu caracter administrativ sau judecătoresc. Reclamantul nu este, totodată, ținut să epuizeze decât recursurile recunoscute ca un drept şi nu socotite ca un privilegiu. De aceea, dacă el trebuie să declare recurs la toate organele judecătoreşti aflate la dispoziția sa, el nu este obligat să sesizeze anumite servicii sociale (ECHR, 1978), nici să ceară grațierea din partea executivului, ceea ce Curtea consideră a fi un 'recurs extraordinar", deci nu unul efectiv (ECHR,1981). 
Conform art. 27 paragraful 1, Curtea nu poate reține nicio cerere anonimă sau care ar fi esențial aceeaşi cu o altă cerere deja examinată de ea sau supusă unei alte instanțe internaționale de anchetă sau de reglementare. În ultimele două cazuri, Curtea poate totuşi sa examineze cererea, dacă ea conține fapte noi pertinente (adica, după interpretarea dată de Curte acestei expresii, care nu erau cunoscute la momentul depunerii cererii). Aceeaşi cauză nu poate fi cercetată decât o singură dată, conform principiului res judicata pro veritate habetur.

Paragraful al doilea al aceluiaşi articol obligă Curtea să declare inadmisibilă o cerere care este incompatibilă cu dispozițiile Convenției, în mod evident neîntemeiată sau abuzivă.

Un alt mod de rezolvare a recursurilor individuale îl reprezintă rezolvarea amiabilă a conflictului. Reglementările amiabile ale situațiilor litigioase pot reprezenta reflectarea concesiilor mutuale facute de către reclamant şi pârât. În realitate, singura concesie pe care o face reclamantul este de a-şi retrage cererea şi de a promite ca nu o va mai înainta altor instanțe internaționale. Statul face, însă, concesii de fond (Gomien, 1996: 156).

\section{Concluzii}

Recunoaşterea persoanelor fizice ca subiecte directe (nu doar indirecte, cum le consideră unii autori) de drept internațional public, mai ales în privinţa apelurilor vizând drepturile omului, poate fi tentantă. Şi asta deoarece procedurile prin care o persoană işsi poate apăra drepturile pe cale individuală sunt mult îngreunate de complexitatea pe care o presupun procedurile, necesită foarte mult timp şi cheltuieli care, de multe ori, prin cuantumul lor, descurajează apelul persoanelor fizice la instanțele internaţionale. Este adevărat că o asemenea recunoaştere ar modifica însăşi fundamentele dreptului internațional public.

În plus, evoluția drepturilor din generația a treia (dreptul la pace, dreptul la dezvoltare, dreptul la un mediu sănătos etc.) relevă tendințe de natură a aduce schimbări în acest domeniu.

$\mathrm{Cu}$ toate acestea, problema dacă indivizii pot fi considerați subiecte de drept internațional este departe de a fi fost tranşată până în prezent, atât în plan normativ, cât şi în doctrină.

\section{Acknowledgement}

Această lucrare a fost elaborată în cadrul cercetării doctorale cu tema „Acceptabilitatea socială şi bioetică a tehnicilor conexe reproducerii umane 
asistate medical în România", realizată în cadrul şi cu finanțarea prin bursă doctorală a Şcolii Doctorale de Sociologie a Universității din Oradea, România. Cercetarea doctorală este efectuată în cotutelă cu Universitatea de Medicină şi Farmacie „Grigore T. Popa” din Iaşi, România.

\section{References}

Adunarea Constituantă. (1991). Constituția României [Constitutuion of Romania]. Republicată. Monitorul Oficial al României, 767, 2003, October 31.

Andronovici, C. (1993). Drept international public [International public law] (1st vol.). Bucharest, Romania: Graphix.

Barbu, I. A. (2008). Afirmarea preocupărilor privind prezenţa directă a persoanelor fizice in mediul internațional, o „sfidare” la adresa caracterului ,interetatic" al dreptului internațional? [Asserting concerns about the direct presence of natural persons in the international environment, a "challenge" to the "interstate" character of international law?]. EIRP Proceedings, 3, 233-235.

Council of Europe. (1950). Convention for the Protection of Human Rights and Fundamental Freedoms. Retrieved from https://www.echr.coe.int/Documents/Convention ENG.pdf

Diaconu, I. (1995). Drept internațional public [International public law] (2nd ed.). Bucharest, Romania: Casa de Editură şi Presă "Şansa" S.R.L.

Dreyfuss, S. (1968). Le droit des relations internationales [International relations law]. Paris, France: Cujas.

European Court of Human Rights (ECHR). (1978). Klass and others v. Germany, Judgement of 06.09.1978. Retrieved from https://hudoc.echr.coe.int/eng\# $\{\% 22$ itemid $\% 22:[\% 22001-57510 \% 22]\}$

European Court of Human Rights (ECHR). (1980). Guzzardi v. Italy,Judgement of 06.11.1980. Retrieved from https://hudoc.echr.coe.int/eng\#\{\%22itemid\%22:[\%22001-57498\%22]\}

European Court of Human Rights (ECHR). (1981). 270 X v.Denmark, Judgement of 16.12.1981. Retrieved from https://www.echr.coe.int/Documents/Research report young people E NG.pdf

Geamănu, G. (1965). Drept international contemporan [Contemporary international law]. Bucharest, Romania: Didactică şi Pedagogică.

Gomien, D. (1996). Introducere in Conventia Europeană a Drepturilor Omului [Introduction to the European Convention on Human Rights]. Bucharest, Romania: All.

Ignătescu, C. (2013). Abuzul de drept [Abuse of rights]. Iaşi, Romania: Lumen. 
Controversies Regarding the Status of the Natural Person in International Public ... Alexandra HUIDU

Janis, M.W. (1984). Individuals as subjects of international law. Cornell International Law Journal, 17(1), 61-78.

Miga-Beşteliu, R. (2003). Drept internaţional. Introducere in dreptul international public [International law. Introduction to public international law] (3rd ed.), Bucharest, Romania: All Beck.

Moca, G. (1983). Drept international [International law] (1st vol.). Bucharest, Romania: Politică.

Niciu, M. (1995). Drept internațional public [International public law] (2nd ed.) (1st vol.). Iaşi, Romania: Editura Fundatiei Chemarea.

Permanent Court of International Justice (PCIJ). (1924). Judgement no. 2/30.08.1924 on the Mavrommatis Palestine Concessions, Greece v. Britain. Retrieved from http://www.worldcourts.com/pcij/eng/decisions/1924.08.30 mavromma tis.htm

Permanent Court of International Justice (PCIJ). (1928a). Advisory opinion no. 15/03.03.1928 on the Jurisdiction of the Courts of Danzig (pecuniary claims of Danzig railway officials who have passed into the Polish service, against the Polish Railways Administration). Retrieved from http://www.worldcourts.com/pcij/eng/decisions/1928.03.03 danzig.htm

Permanent Court of International Justice (PCIJ). (1928b). Judgement no. 13/13.09.1928 on The factory at Chorzow (claim for indemnity), Germany v. Poland. Retrieved from http://www.worldcourts.com/pcij/eng/decisions/1928.09.13 chorzow1.h $\underline{\mathrm{tm}}$

Permanent Court of International Justice (PCIJ). (1939). Judgement no. 29/29.02.1939 on The Panevezys-Saldutiskis Railway Case, Estonia v. Lithuania. Retrieved from http://www.worldcourts.com/pcij/eng/decisions/1939.02.28 panevezyssaldutiskis.htm

Popa, V., Petrişor, P., \& Cozmâncă, O. (1994). Elemente de drept internaţional public [Elements of international public law]. Timişoara, Romania: Presa Universitară Română.

Reuter, P. (1993). Droit international public [International public law] (7th ed.). Paris, France: Presses Universitaires de France.

United Nations (UN). (1948). The Universal Declaration of Human Rights. Retrieved from https://www.un.org/en/universal-declaration-humanrights/

United Nations General Assembly (UN). (1965). International Convention on the Elimination of All Forms of Racial Discrimination. Retrieved from https://www.ohchr.org/en/professionalinterest/pages/cerd.aspx 
United Nations General Assembly (UN). (1966a). International Covenant on Economic, Social and Cultural Rights. Retrieved from https://www.ohchr.org/en/professionalinterest/pages/cescr.aspx

United Nations General Assembly (UN). (1966b). International Covenant on Civil and Political Rights. Retrieved from https://www.ohchr.org/en/professionalinterest/pages/ccpr.aspx 